Samodra Wibawa

Direktori/DISERTASI/ADM INISTRASI_PENDIDIKAN /Djaiz_Dujo_Pengaruh_Pen erapan_Sistem_Administrasi _Partisipatif.pdf, diakses 5 Desember 2011

Kahar, Irawaty A. (2008). Konsep

Kepemimpinan dalam Perubahan Organisasi (Organizational Change) pada Perpustakaan Perguruan Tinggi dalam Pustaha: Jurnal Studi Perpustakaan dan Informasi, Vol.4, No.1

Elu, Wilfridus B. dan Agus Joko Purwanto. (2011). Inovasi dan Perubahan Organisasi, Jakarta: UT

Prawirodirdjo, Arto Suharto. (2007). Analisis Pengarus Perubahan Organisasi dan
Budaya Organisasi terhadap Kepuasan dan Kinerja Pegawai Kantor Direktorat Je nd e r a l P a jak, Te s is Magister Manajemen UNDIP, Semarang

R obbin s, S t e p he n P. ( 2003 ). Organizational Behavior, New Jersey: Prentice Hall

Wibawa, Samodra. (2005). Peluang Penerapan New Public Management untuk Kabupaten di Indonesia, Jogja: Gadjah Mada University Press

Yuwono, C.D. Ino dan M.G. Bagus Ani Putra. (2005). Faktor Emosi dalam Proses Perubahan Organisasi dalam Jurnal INSAN Vol. 7 No. 3

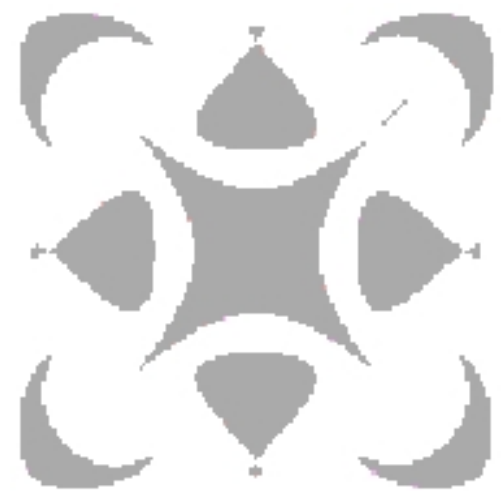




\title{
KEPENTINGAN POLITIK DAN EKONOMI KEPALA DAERAH DALAM REFORMASI BIROKRASI :

\author{
Kasus Reformasi Pelayanan Perizinan Di,Kabupaten Gowa Dan
} Kabupaten Takalar
}

\section{POLITICAL AND ECONOMIC INTERESTS OF REGIONAL HEAD IN THE REFORM OF THE BUREAUCRACY (The Case Of Permit Service Reform In Gowa \& Takalar Regency)}

\author{
Andi Luhur Prianto \\ Jurusan IImu Pemerintahan \\ Fakultas IImu Sosial \& IImu Politik Universitas Muhammadiyah Makassar \\ Gedung F I Lt. 1 Pusat Perkantoran FISIP Unismuh \\ JI. Sultan Alauddin No. 259 Makassar \\ Email : luhur_gov@yahoo.com
}

\begin{abstract}
The design of decentralization has given specific space for government bureaucracy to create and innovation the acceleration of development territory. At this point in the required skills apparatuses with forward thinking to achieve a professional bureaucracyin an institutional mechanism that is efficient, effective and equity. Institutional arrangement bureaucracyis not geared to improve the quality of public services, but in order to accommodate the practice of politicization of bureaucracy in perpetuating oligarchy of power head area.

The purpose of this study to answer the questions: (1.) How is the actual picture of the practice of bureaucratic reform licensing services in Gowa and Takalar regency, (2.) What is the connection the interests of regional heads in bureaucratic reform licensing services in Gowa and Takalar regency.

The reserach aimed that the licensing service reforms under taken by the local government, Gowa and Takalar Regency likely still partial, in which the reform is based on the basic needs and regulatory pressure center. Orientation of the provision of services also permit limited to the normative aspect alone. In both regions, the character possessed strong leadership allows the behavior of the regional head office personnel licensing services oriented to meet the political and economic objectives of the head region.
\end{abstract}

Keywords : bureaucratic reform, local, services, licensing

Naskah diterima pada 3 November 2012 
KEPENTINGAN POLITIK DAN EKONOMI KEPALA DAERAH DALAM REFORMASI BIROKRASI : KASUS REFORMASI PELAYANAN PERIZINAN DI KABUPATEN GOWA DAN KABUPATEN TAKALAR

Andi Luhur Prianto

\begin{abstract}
Abstrak
Desain desentralisasitelah memberi ruang gerak yang spesifik kepada birokrasi pemerintah daerah untuk berkreasi dan berinovasi dalam akselerasi pembangunan diwilayahnya. Pada posisi ini dituntut kemampuan Sumber DayaAparatur dengan visi yang jauh kedepan (forward thinking) untuk mewujudkan profesionalisme birokrasi dalam sebuah mekanisme kelembagaan yang efisien, efektif dan berkeadilan (equity).Penataan kelembagaan birokrasi bukan diarahkan untuk meningkatkan kualitas pelayanan publik, tetapi demi mengakomodasi praktek politisasi birokrasi dalam melanggengkan oligarki kekuasaan kepala daerah.

Tujuan penelitian ini untuk menjawab pertanyaan : (1).Bagaimanakah gambaran aktual tentang praktek reformasi birokrasi pelayanan perizinan di Kabupaten Gowa dan Kabupaten Takalar, (2.) Bagaimanakah kaitan kepentingan-kepentingan kepala daerah dalam reformasi birokrasi pelayanan perizinan di Kabupaten Gowa dan Kabupaten Takalar?

Hasil penelitianmenujukkan bahwa reformasi pelayanan perizinan yang dilakukan oleh pemerintah daerah, yakni kabupaten Gowa dan Kabupaten Takalar cenderung masih parsial, di mana reformasi dilandasi atas dasar kebutuhan dan desakan peraturan pusat. Orientasi penyelenggaraan pelayanan perizinan juga hanya terbatas pada aspek normatif semata.Pada kedua daerah ini, karakter strong leadership yang dimiliki kepala daerah memungkinkan perilaku aparatur kantor pelayanan perizinan diorientasikan untuk memenuhi tujuan politik dan ekonomi sang kepala daerah.
\end{abstract}

Kata kunci: reformasi birokrasi, daerah, pelayanan, perizinan

\section{PENGANTAR}

Desentralisasi yang mengemuka dalam konstruksi reformasi telah menunjukkan wataknya sebagai antitesis nyata atas setting penyelenggaraan pemerintahan yang berjalan selama ini.Semangat desentralisasi yang berkobar terus menyulut pemerintah daerah untuk memaksimalkan besaran kewenangan yang dimiliki dalam aktivitas pembangunan dan pelayanan publik. Desain desentralisasitelah memberi ruang gerak yang spesifik kepada birokrasi pemerintah daerah untuk berkreasi dan berinovasi dalam akselerasi pembangunan diwilayahnya. Pada posisi ini dituntut kemampuan Sumber DayaAparatur dengan visi yang jauh kedepan (forward thinking) untuk mewujudkan profesionalisme birokrasi dalam sebuah mekanisme kelembagaan yang efisien, efektif dan berkeadilan (equity).

Te r l e p a s d a riber b a g i pencapaian beberapa derah otonom dalam melakukan reformasi birokrasi, namun secara umum penilaian tentang progress perubahan setting birokrasi belum menunjukkan capaian yang memuaskan.Berbagai penilaian dari survey lembaga-lembaga independen memberikan bukti kuat tentang 
persepsi publik yang rendah tentang kinerja birokrasi pasca otonomi daerah.Stereotipe tentang korupsi, kolusi dan nepotisme tetap menjadi "cacat bawaan" yang membayangi segala aktivitas pemerintah daerah dalam menata mesin pemerintahannya. Salah satu contoh dari masih rendahnya komitmen pemerintah daerah dalam melakukan inisiasi pencegahan korupsi seperti terlihat pada Penilaian Inisiatif Anti Korupsi (PIAK) Tahun 2011 oleh Komisi Pemberantasan Korupsi (KPK), yang menujukkan bahwa capaian nilai rata-rata masih berada pada level yang rendah atau 4,5 (skala 0-10). Hasil ini mengindikasikan bahwa secara umum faktor inisiatif internal kelembagaan pemerintah pusat dan daerah yang masih rendah dalam menata organisasi pemerintahan.

Fenomena ini tentu sesuatu wajar bagi pihak-pihak yang selama ini intens memperhatikan aktivitas birokrasi di daerah. Dalam banyak hal, reformasi di daerah sering "dibajak" kepala daerah sendiri. Penataan kelembagaan birokrasi bukan diarahkan untuk meningkatkan kualitas pelayanan publik, tetapi demi mengakomodasi praktek politisasi birokrasi dalam melanggengkan oligarki kekuasaan kepala daerah. Reformasi birokrasi kadang hanya berakhir pada penataan strukutur demi mengakomodasi kepentingan pejabat tertentu dalam pola interaksi politis-transaksional. Pada titik ini spirit reformasi birokrasi yang mengusung profesionalisme, merit system, dan impersonalitas hanya sekedar jargon karena tersandera kepentingan politik kepala daerah untuk mengukuhkan oligarki kekuasaannya.
Agenda-agenda besar reformasi birokrasi secara nasional dalam berbagai paket kebijakan seperti bergerak tidak linier dengan semangat reformasi birokrasi oleh pemerintah daerah. Lahinya UU No. 28 Tahun 1999 tentang Penyelenggaraan Negara Yang Bersih dan Bebas dari Korupsi, Kolusi, dan Nepotisme, UU No. 32 Tahun 2004 Tentang Pemerintahan Daerah, UU No. 25 Tahun 2009 Tentang Pelayanan Publik hingga Perpres No. 81 Tahun 2010 Tentang Grand Desaign Reformasi Birokrasi 2010-2025, secara beragam direspons pemerintah daerah. Lemahya kontrol publik dalam memberikan pengawasan terhadap kinerja birokrasi semakin membuat arah reformasi birokrasi di daerah mengalami disorientasi makna.Birokrasi pemerintah daerah ibarat terkurung dalam "rumah kaca", yang hanya bisa menjadi saksi atas perubahan yang terjadi disekitarnya.

Design minimal dari reformasi birokrasi diorientasikan untuk memperoleh sebuah kinerja yang di dalamnya menggambarkan proses demokratisasi, efektifitas, efisiensi, transparansi dan akuntabilitas, serta tanggungjawab dalam kerangka memberikan pelayanan prima kepada masyarakat. Resultante dari seluruh aktivitas reformasi birokrasi adalah tumbuhkembangnya pelayanan prima.Di dalam tipe ideal birokrasi, maka tercermin proses demokrasi yang tercermin darimerit system, sistem remunerasi, serta rewards and punishment.

Salah satu produk reformasi birokrasi yang banyak mendapat sorotan yang luas dari publik adalah kinerja organisasi pelayanan terpadu satu pintu (PTSP). Gagasan dan 
KEPENTINGAN POLITIK DAN EKONOMI KEPALA DAERAH DALAM REFORMASI BIROKRASI : KASUS REFORMASI PELAYANAN PERIZINAN DI KABUPATEN GOWA DAN KABUPATEN TAKALAR

Andi Luhur Prianto

praktek dari one-stop services (OSS) ini dihadirkan sebagai upaya untuk meretas belitan dari panjangnya mata rantai birokrasi dalam menyediakan layanan, terutama layanan yang terkait denganperizinan investasi. Ikhtiar untuk mengitegrasikan berbagai jenis pelayanan publik yang terkait pada suatu unit yang berdiri sendiri merupakan implementasi dari Permendagri No. 24 Tahun 2006 tentang Pedoman Pendirian Pelayanan Terpadu Satu Pintu dan Peraturan Menteri Dalam Negeri Nomor 20Tahun 2008 tentang Pedoman Organisasi dan Tata Kerja Unit Pelayanan Perizinan Terpadu di Daerah. Layanan terpadu satu pintu merupakan kegiatan penyelenggaraan perizinan dan non perizinan yang proses pengelolaannya dimulai dari tahap permohonan sampai ketahap terbitnya dokumen dilakukan pada satu tempat. Tujuan pokok yang ingin diperoleh guna memberikan akses yang lebih luas kepada masyarakat untuk memperoleh layanan publik secara transparan baik dari sisi waktu, biaya, persyaratan maupun prosedur yang harus ditempuh (Jasin dkk, 2007).

Kewenangan penataan pelayanan terpadu satu pintu (PTSP) di bidang pelayanan perizinan telah merasakan dampak langsung dari otonomi daerah, dimana semakin besarnya kewenangan kepala daerah dalam menggerakan birokrasi pemerintah daerah justru tidak kongruen dengan kinerja pelayanan.Kinerja pelayanan publik bidang perizinan masih dihadapkan pada berbagai kekurangan, seperti kurang reponsif, kurang informatif, kurang koordinasi, dan in-efisien. Menjadi keniscayaan jika kemudian kalangan dunia usaha sering mengeluhkan proses pelayanan perizinan yang diselenggarakan oleh pemerintah atau pemerintah daerah, yang dirasakan berbelit-belit, tidak transparan, tidak ada kejelasan dan kepastian waktu, dan adanya biaya ekstra.

Perizinan merupakan salah satu aspek penting dalam pelayanan publik, demikian juga perizinan yang terkait dengan kegiatan usaha. Proses perizinan, khususnya perizinan usaha, secara langsung akan berpengaruh terhadap keinginan dan keputusan calon pengusaha maupun investor untuk menanamkan modalnya. Demikan pula sebaliknya, jika proses perizinan tidak efisien, berbelit-belit, dan tidak transparan baik dalam hal waktu, biaya, maupun prosedur akan berdampak terhadap menurunnya keinginan orang untuk mengurus perizinan usaha, dan mereka mencari tempat investasi lain yang prosesnya lebih jelas dan transparan. Hal ini tentu saja selanjutnya akan berdampak terhadap ketersediaan lapangan kerja dan masalah-masalah ketenagakerjaan lainnya (Mursitama dkk, 2010).

Sudah menjadi rahasia umum bahwa masyarakat sangat enggan berhubungan dengan birokrasi pemerintah (Atmoko dkk, 2007, Dwiyanto et al, 2006). Kurangnya transparansi baik dari sisi waktu, persyaratan, biaya maupun prosedur ditambah dengan masih kentalnya prilaku koruptif merupakan kondisi nyata yang terjadi dan dihadapi oleh setiap masyarakat indonesia saat ini. Transparancy International (TI), sebuah lembaga independen berbasis di Berlin-Jerman tiap tahun mengeluarkan Indeks Persepsi Korupsi (IPK) bagi tiap negara. Pada 2011, IPK 
Indonesia berada pada angka 3,0 (skala 1-10), sehingga menjadi catatan bagi pemerintah agar lebihserius melakukan perbaikan terhadap proses perizinan usaha. (TII, 2012).

Menurut Atmoko dkk (2007), kalangan dunia usaha masih mengeluhkan dan merasakan dalam proses dan pelaksanaan pemberian layanan di kebanyakan daerah, masih belum banyak perubahan signifikan. Keluhan dan ketidakpuasan dunia usaha belum teratasi, terutama berkaitan keluhan yang berhubungan dengan biaya tinggi dan ketidak pastian hukum bagi pengusaha, akibat belum berubahnya orientasi pemerintahan daerah terhadap hubungan perizinan dengan pendapatan asli daerah (PAD), dan tarik menarik kewenangan antara pemerintah dan pemerintahan daerah. Hasil kajian dari Litbang KPK (Jasin dkk, 2007) pada bidang Pelayanan Perizinan dan Non Perizinan menunjukkan bahwa adanya pelimpahan kewenangan pengelolaan perizinan dari pemerintah pusat ke kabupaten/kota harus diikuti dengan penyederhanaan jenis perizinan, terutama yang memiliki fungsi yang hampir sama (misal. TDP dan SIUP) dan menyatukan jenis perizinan yang pengurusannya bisa dilakukan secara paralel (misal SITU dan HO paralel dengan SIUP, TDP, IUI dan TDI). Temuan ini menjadi sangat relevan ditengah upaya percepatan reformasi birokrasi perizinan yang masih relatif berbelit-belit.

Dalam upaya mengoptimalkan integrasi pelayanan perizinan, maka pemerintah Kabupaten Gowa dan Kabupaten Takalar di Provinsi Sulawesi Selatan telah melakukan aransemen birokrasi pelayanan
publik.Kedua kabupaten, yang menjadi penyangga aktivitas Kota Makassar di bagian selatan, ini telah menjalankan praktek penataan kelembagaan pelayanan. Penataan organisasi pemerintah daerah sebagai bentuk reformasi birokrasi dilakukan berdasarkan PP No. 8 Tahun 2003 tantang Pedoman Organisasi Perangkat Daerah maupun PP No. 41 tahun 2007 Tentang Organisasi Perangkat Daerah. Meskipun demikian, nuansa perubahan dari produk kebijakan tersebut masih bersifat "setengah hati" dan cenderung "mengangsur" pelimpahan jenis-jenis layanan pada organisasi pelayanan terpadu yang dibentuknya sendiri.

Di Kabupaten Gowa misalnya, pendirian Kantor Pelayanan Terpadu telah dilakukan meskipun tidak sertamerta diikuti oleh pendelegasian seluruh jenis layanan perizinan. Terdapat beberapa jenis layanan perizinan yang strategis seperti izin usaha pertambangan dan jasa-jasa lingkungan tetap di tempatkan pada organisasi Sekretariat Daerah.Prosedur pelayanan terpadu yang berusaha dibangunbelum optimal sebabbelum terlihat upaya untuk mendelegasikan kewenangan yang dimiliki kepala daerah secara utuh berdasarkan prinsip-prinsip reformasi birokrasi, yang menuntut peningkatan kualitas layanan secara terpadu, transparan dan tanpa biaya-biaya ekstra.Pada situasidi Kabupaten Takalar, kondisi yang tidak lebih baik juga diaktualisasikan pada praktek reformasi birokrasi pelayanan perizinan cenderung lebih terpadu. Kantor Pelayanan Terpadu tidak banyak menangani layanan perizinan, justru yang layanan utama ditangani adalah adalah layanan-layanan nonperizinan. Beberapa jenis layanan 
KEPENTINGAN POLITIK DAN EKONOMI KEPALA DAERAH DALAM REFORMASI BIROKRASI : KASUS REFORMASI PELAYANAN PERIZINAN DI KABUPATEN GOWA DAN KABUPATEN TAKALAR

Andi Luhur Prianto

perizinan yang strategis masih tersebar di beberapa instansi teknis seperti perizinan penanaman modal yang dikelola Kantor Lingkungan Hidup dan Penanaman Modal dan sebagian lagi berada di bawah kendali langsung sang kepala daerah. Kondisi ini menujukkan bahwa reformasi birokrasi yang di pimpin oleh sang kepala daerah, belum berhasil mengintegrasikan pelayanan publik yang efesien, efektif, dan equity.

Berdasarkan uraian sebelumnya, maka dalam menilai secara komparatif tarikan-tarikan kepentingan kepala daerah dalam praktek reformasi birokrasi pelayanan perizinan didaerah, maka pokok permasalahan yang hendak dikedepankan dalam kajian ini adalah (1.) bagaimakah gambaran aktual tentang praktek reformasi birokrasi pelayanan perizinan di Kabupaten Gowa dan Kabupaten Takalar ? (2.) Bagimanakah kaitan kepentingan-kepentingan kepala daerah dalam reformasi birokrasi pelayanan perizinan di Kabupaten Gowa dan Kabupaten Takalar?

Dengan demikian maka tujuan penulisan artikel adalah untuk mengetahui gambaran aktual tentang praktek reformasi birokrasi pelayanan perizinan di Kabupaten Gowa dan $\mathrm{K}$ a bu paten Ta kalardanun t u k mengetahui kaitan kepentingankepentingan kepala daerah dalam reformasi birokrasi pelayanan perizinan di Kabupaten Gowa dan Kabupaten Takalar.

\section{METODE PENELITIAN \\ 1) Metode Penelitian}

Penelitian ini bersifat deskriptif(Bungin, 2003) dengan mempergunakan data kualitatif maupun kuantitatif. Dalam penelitian kualitatif, tantangan utama peneliti adalah adalah bagaimana menentukan informan kunci (key informan) yang sarat informasi sesuai dengan fokus penelitian (Bungin, 2003). Mengingat dasar penelitian ini bersifat kualitatif sehingga metode pengumpulan data lebih banyak dengan indepth intervieuw dengan key informan yang terpilih.

\section{2) Teknik Pengumpulan Data}

Untuk mendapatkan data sekunder dan data primer yang akurat maka penulis menggunakan teknik pengumpulan data sebagai berikut:

1. S t u d i Pus taka ( Library Research)

Dalam studi pustaka ini penulis berusaha menelaah berbagai bahan bacaan/pustaka serta dokumen-dokumen lainnya yang mempunyai relevansi dengan masalah yang akan diteliti.

2. Studi Lapangan (Field Research) Studi lapangan ini dimaksudkan yaitu penulis langsung melakukan penelitian pada lokasi atau obyek yang telah ditentukan, dengan cara sebagai berikut:

a. W a w a n c a r a , yaitu mengadakan tanya jawab langsung kepada informan yang memiliki informasi tentang aspek akuntabilitas publik pada OMS.

b. Focussed Group Discussion (FGD), yaitu teknik pengumpulan melalui disksusi kelompok terarah 
pada beberapa key informan.

\section{3) Analisa Data}

Data dalam penelitian ini merupakan data primer yang diperoleh dilapangan dari hasil wawancara yang mendalam dan FGD dari informan dan key informan. Data yang terkumpul kemudian dianalisis secara deskriptif sesuai dengan tujuan penelitian melalui indikatorindikator yang telah ditetapkan.

\section{KERANGKA TEORI}

\section{1) Reformasi Birokrasi}

Demokratisasi politik, desentralisasi pemerintahan dan liberalisasi ekonomi yang berlangsung dengan cepat sejak era reformasi ternyata tidak diikuti oleh perubahan tata penyelenggaraan pemerintahan yang cukup mendasar. Sistem pemerintahan, termasuk pranata-pranata yang diperlukan untuk mendukung sistem politik demokratis, otonomi daerah dan sistem ekonomi pasar yang lebih terbuka belum sepenuhnyatersedia. Salah satu pranata tersebut adalah sistem birokrasi publik yang terdiri atas 3 komponen pokok yaitu peraturan dasar tentangsistem birokrasi, sistem kepegawaian, akuntabilitas dan transparansi (Insani, 2010). Kondisi inilah yang menyebabkan kebijakan reformasi birokrasi yang dicanangkan pada kurun waktu tersebut tidak berjalan dengan baik. Ruang lingkup reformasi birokrasi yang terbatas dan tanpa didukung oleh grand strategy yang konfrehensif yang berakibat pada terjadilah fragmentasi dalam tata kelola pemerintahan. Sebagai contoh, pemisahan kekuasaan antara legislatif dan eksekutif tidak sepenuhnya ditaati karena ada kewenangan eksekutifyang dijalankan oleh kekuasaan legislatif, padahal lembaga ini tidak memiliki kapasitas kelembagaan untuk melakukan tugas tersebut. Reformasi birokrasi yang dilaksanakan yang pada hakekatnya ditujukan untuk membangun/membentuk profil dan perilaku aparatur negara yang memiliki: 1) Integritas Tinggi, yaitu: perilaku aparatur negara yang dalam bekerja senantiasa menjaga sikap profesional dan menjunjung tinggi nilai-nilai moralitas (kejujuran, kesetiaan, komitmen) serta menjaga keutuhan pribadi; 2) Produktivitas Tinggi dan Bertanggungjawab, yaitu: hasil optimal yang dicapai oleh aparatur negara dari serangkaian program kegiatan yang inovatif, efektif dan efisien dalam mengelola sumber daya yang ada serta ditunjang oleh dedikasi dan etos kerja yang tinggi, dan 3) Kemampuan Memberikan Pelayanan yang Prima, yaitu: Kepuasan yang dirasakan oleh publik sebagai dampak dari hasil kerja birokrasi yang profesional, berdedikasi dan memiliki standar nilai moral yang tinggi dalam menjalankan tugasnya sebagai abdi negara dan abdi masyarakat, utamanya dalam memberikan pelayanan prima kepada publik dengan sepenuh hati dan rasa tanggungjawab. Sedangkan sasaran Kebijakan RB yang ingin capai adalah mengubah pola pikir (mind 
KEPENTINGAN POLITIK DAN EKONOMI KEPALA DAERAH DALAM REFORMASI BIROKRASI : KASUS REFORMASI PELAYANAN PERIZINAN DI KABUPATEN GOWA DAN KABUPATEN TAKALAR

Andi Luhur Prianto

set), budaya kerja (culture set) serta sistem manajemen pemerintahan (Nugroho, 2010).

Tujuan dan sasaran ini dilaksanakan melalui Sembilan program dengan dua puluh tiga kegiatan untuk Gelombang Pertama dan limapuluh empat untuk Gelombang Kedua. Adapun kesembilan program tersebut adalah: (1) Quick Wins, (2) Manajemen Perubahan, (3) Penataan dan Penguatan Organisasi, (4) Penataan Tatalaksanaan, (5) Penataan Sistem Manajemen SDM Aparatur, (6) Penyusunan Peraturan Perundangundangan, (7) Penataan

Pengawasan Internal, (8)

Peningkatan Akuntabilitas Kinerja, dan (9) Peningkatan Kualitas Pelayanan Publik.

Dalam rangka pencapaian tujuan dan sasaran kebijakan reformasi tersebut maka telah ditetapkan strategi implementasi kebijakan yang tertuang di dalam Keputusan Menteri Pendayagunaan Apartur Negara Nomor PER/15/M.PAN/7/2008 Tentang

Pedoman Umum Reformasi Birokrasi beserta peraturanperaturan yang mengikutnya, antara lain: Peraturan MenPAN Nomor PER/19/M.PAN/11/2008 Tentang Petunjuk Pelaksanaan Evaluasi Kinerja Organisasi Pemerinah; $\mathrm{P}$ e r a t u r a n M e n PA N N o m or PER/21/M.PAN/11/2008 Tentang

Pedoman Penyusunan Standar Operasional Prosedur (SOP) Administrasi Pemerintahan;

$\mathrm{P}$ e r a t u r a $\mathrm{n} \mathrm{M}$ e $\mathrm{n}$ PA $\mathrm{N} \mathrm{N}$ o m o r PER/04/M.PAN/4/2009 Tentang Pedoman Pengajuan Dokumen
Usulan RB di Lingkungan

Kementerian/Lembaga/ Pemerintah Daerah; Peraturan Presiden Nomor 81 Tahun 2010 Tentang Grand Design Reformasi Birokrasi 20102025. Strategi terdiri atas strategi implementasi dan program implementasi reformasi yang dilengkapi dengan kegiatan monitoring dan evaluasi serta kegiatan pengorganisasian dan pembiayaan.

Strategi implementasi ini disusun mengingat sangat luasnya cakupan reformasi birokrasi yaitu dari seluruh instansi yang ada di tingkat pusat (lembaga negara, kementerian dan lembaga pemerintah) maupun yang ada di tingkat daerah (Provinsi dan Kabupaten/Kota). Untuk memberikan kemudahan dalam implementasi maka strategi implementasi ini dimanifestasikan dalam bentuk tahapan, program dan aktivitas reformasi birokrasi. Adapun isi stategi implementasi tersebut adalah: 1) Proses membangun kepercayaan masyarakat melalui Program Percepatan (Quick Wins) yang berdampak pada perbaikan sistem kerja dan perbaikan kualitas produk utama; 2) Proses membangun komitmen dan partisipasi mealui Manajemen Perubahan yang berdampak pada terkomunikasikannya perubahan baik kepada pegawai maupun kepada masyarakat dalam rangka pembentukan perilaku yang diinginkan; 3) Proses mengubah pola pikir, budaya dan nilai-nilai kerja melalui penataan sistem yang berdampak pada perbaikan 
organisasi, ketatalaksanaan dan sistem manajemen SDM, dan 4)Proses memastikan keberlangsungan berjalannya sistem dan terjadinya perubahan melalui penguatan unit organisasi, deregulasi-regulasi, penginkatan sistem pengawasan, perbaikan/ pengadaan sarana dan prasarana yang berdampak pada perubahan pola pikir, perubahan budaya kerja dan perubahan perilaku (Insani, 2010).

\section{2) Reformasi Pelayanan Perizinan Di Era Otonomi Daerah}

Dalam pengertian sempit, pelayanan terpadu dapat diartikan sebagai satu instansi pemerintah yang memiliki semua otoritas yang diperlukan untuk memberi berbagai layanan perizinan (licenses,permits, approvals and clearances). Tanpa otoritas yang mampu menangani semua urusan tersebut instansi pemerintah tidak dapat mengatur pelbagai pengaturan selama proses. Oleh sebab itu, dalam hal ini instansi tersebut tidak dapat menyediakan semua bentuk perizinan yang diperlukan dalam pelbagai tingkat administrasi sehingga harus bergantung pada otoritas lain (Mursitama dkk, 2010).

Pelayanan perizinan dengan sistem terpadu satu pintu (one stop service) membuat waktu pembuatan izin menjadi lebih singkat. Pasalnya, dengan pengurusan administrasi berbasis teknologi informasi, input data cukup dilakukan sekali, dan administrasi bisa dilakukan secara simultan. Dengan adanya kelembagaan pelayanan terpadu satu pintu, seluruh perizinan dan non-perizinan yang menjadi kewenangan kabupaten/kota dapat terlayani dalam satu lembaga.

Harapan yang ingin dicapai adalah mendorong pertumbuhan ekonomi melalui peningkatan investasi dan bertujuan meningkatkan kualitas layanan publik.

Reformasi pelayanan terpadu pada dasarnya telah diatur melalui Permendagri No. 24 Tahun 2006 mengenai Pedoman Penyelenggaran Pelayanan Terpadu Satu Pintu. Dalam peraturan ini, pelayanan atas permohonan perizinan dan nonperizinan dilakukan oleh Perangkat Daerah Penyelenggara Pelayanan Terpadu Satu Pintu (PPTSP), yaitu perangkat pemerintah daerah yang memiliki tugas pokok dan fungsi mengelola semua bentuk pelayanan perizinan dan non-perizinan di daerah dengan sistem satu pintu. Dengan kewenangan tersebut, keberadaan kelembagaan layanan terpadu merupakan salah satu upaya pemenuhan kewajiban pemerintah daerah kabupaten/kota kepada masyarakat.Beragamnya layanan yang terwadahi pada kelembagaan layanan terpadu merupakan perwujudan pelaksanaan kewenangan kabupaten/kota dalam upaya mempercepat peningkatan kesejahteraan masyarakat dan meningkatkan efisiensi dan efektivitas pemerintahan daerah.Upaya yang dilakukan pemerintah dalam meningkatkan pelayanan dalam hal perizinan adalah melalui ditetapkannya Peraturan Menteri Dalam Negeri No. 24 Tahun 2006 tentang 
KEPENTINGAN POLITIK DAN EKONOMI KEPALA DAERAH DALAM REFORMASI BIROKRASI : KASUS REFORMASI PELAYANAN PERIZINAN DI KABUPATEN GOWA DAN KABUPATEN TAKALAR

Andi Luhur Prianto

Pelayanan Perizinan Terpadu Satu Pintu yang bertujuan untuk meningkatkan kualitas layanan publik serta memberikan akses yang lebih luas kepada masyarakat untuk memperoleh pelayanan publik serta terwujudnya pelayanan publik yang cepat, murah, mudah, transparan, pasti dan terjangkau meningkatnya hak-hak masyarakat terhadap pelayanan publik, hal lain yang diatur dalam peraturan tersebut pada intinya membahas pengaturan mengenai :

a. Penyederhanaan Pelayanan

Dalam Pasal 4 Permendagri 24

Tahun 2006, Bupati/Walikota wajibmelakukan

penyederhanaan

penyelenggaraan pelayanan

terpadu satu pintu dan

Penyederhanaan

penyelenggaraan pelayanan

mencakup :

? pelayanan atas permohonan perizinan dan non perizinan dilakukan oleh PPTSP;

? percepatan waktu proses penyelesaian pelayanan tidak melebihi standar waktu yang telah ditetapkan dalam peraturan daerah;

? kepastian biaya pelayanan tidak melebihi dari ketentuan yang telahditetapkan dalam peraturan daerah;

? kejelasan prosedur pelayanan dapat ditelusuri dan diketahui setiaptahapan proses pemberian perizinan dan non perizinan sesuai dengan urutan prosedurnya;

? mengurangi berkas kelengkapan permohonan perizinan yang samauntuk dua atau lebih permohonan perizinan;

? pembebasan biaya perizinan bagi Usaha Mikro Kecil Menengah (UMKM) yang ingin memulai usaha baru sesuai dengan peraturanyang berlaku; dan

? pemberian hak kepada masyarakat untuk memperoleh informasi dalamkaitannya dengan penyelenggaraan pelayanan.

b. P e r a n g k a t Daerah

Penyelenggara Pelayanan

Terpadu Satu Pintu

Pembentukan perangkat daerah yang menyelenggarakan pelayanan terpadu satu pintu berpedoman pada peraturan perundang-undangan yang mengatur mengenai pembentukan organisasi perangkat daerah. Kemudian lebih jauh Perangkat daerah tersebut harus memiliki sarana dan prasarana yang berkaitan dengan mekanisme pelayanan.

Berkenaan dengan hal tersebut, Bupati/Walikota mendelegasikan kewenangan penandatanganan perizinan dan non perizinan kepada Kepala PPTSP untuk mempercepat proses pelayanan. Lingkup tugas PPTSP meliputi pemberian 
KEPENTINGAN POLITIK DAN EKONOMI KEPALA DAERAH DALAM REFORMASI BIROKRASI : KASUS REFORMASI PELAYANAN PERIZINAN DI KABUPATEN GOWA DAN KABUPATEN TAKALAR

Andi Luhur Prianto

pelayanan atas semua hentuk pelayanan perizinan dan non perizinan yang menjadi kewenangan Kabupaten / Kota dengan mengacu pada prinsip koordinasi, integrasi, sinkronisasi, dan kearnanan berkas.Perangkat Daerah yang secara teknis terkait dengan PPTSP berkewajiban dan bertanggungjawab untuk melakukan pembinaan teknis dan pengawasan atas pengelolaan perizinan dan non perizinan sesuai dengan bidang tugasnya.

c. Proses, waktu dan biaya penyelenggaraan pelayanan Berkenaan dengan proses, waktu dan biaya Pengolahan dokumen persyaratan perizinan dan non perizinan mulai dari tahap permohonan sampai dengan terbitnya dokumen dilakukan secara terpadu satu pintu. Proses penyelenggaraan pelayanan perizinan dilakukan untuk satu jenis perizinan tertentu atau perizinan paralel.

d. Sumber daya manusia

Pegawai yang ditugaskan di lingkungan PPTSP diutmmakan mempunyai kompetensi di bidangnya dan dapat diberikan tunjangan khusus yang besarannya ditetapkan dengan Peraturan Bupati/Walikota sesuai dengan kemampuan keuangan daerah, hal lainnya Pemerintah Daerah berkewajiban untuk melakukan pengembangan sumber daya manusia pengelola pelayanan terpadu satu pintu secara berkesinambungan.

Keterbukaan informasi PPTSP wajib menyediakan dan menyebarkan informasi berkaitan dengan jenis pelayanan dan persyaratan teknis, mekanisrne, penelusuran posisi dokumen pada setiap proses, biaya dan waktu perizinan dan non perizinan, serta tata cara pengaduan, yang dilakukan secara jelas melalui berbagai media yang mudah diakses dan diketahui oleh masyarakat.

Penanganan pengaduan PPTSP wajib menyediakan sarana pengaduan dengan menggunakan media yang disesuaikan dengan kondisi daerahnya dan PPTSP wajib menindaklanjuti pengaduan masyarakat secara tepat, cepat, dan memberikan jawaban serta penyelesaiannya kepada pengadu paling lama 10 (sepuluh) hari kerja. Kepuasan masyarakat PPTSP wajib melakukan penelitian kepuasan rnasyarakat secara berkala sesuai peraturan perundang-undangan. Pembinaan dan pengawasan Pembinaan atas penyelenggaraan pelayanan terpadu satu pintu dilakukan 
KEPENTINGAN POLITIK DAN EKONOMI KEPALA DAERAH DALAM REFORMASI BIROKRASI : KASUS REFORMASI PELAYANAN PERIZINAN DI KABUPATEN GOWA DAN KABUPATEN TAKALAR

Andi Luhur Prianto

secara berjenjang dan berkesinambungan oleh Menteri Dalam Negeri dan Kepala

Daerah sesuai dengan kewenangan masing-masing dalam rangka meningkatkan dan mempertahankan mutu pelayanan perizinan dan non perizinan. Pengawasan terhadap proses penyelenggaraan pelayanan terpadu satu pintu dilakukan oleh aparat pengawas intern pemerintah sesuai dengan fungsi dan kewenangannya.

i. Kerja Sama

Dalam pengembangan PPTSP, Bupati/Walikota dapat melakukan kerjasama dengan pihak perguruan tinggi, lembaga swadaya masyarakat,asosiasi usaha, lembaga-lembaga internasional, dan dengan pemangkukepentingan lainnya sesuai dengan peraturan perundang-undangan.

j. Pelaporan

B u p a t i d a $\mathrm{n} \mathrm{Wa} \mathrm{li} \mathrm{k} \mathrm{o} \mathrm{t} \mathrm{a}$ menyampaikan laporan secara tertulis kepadA Gubernur mengenai perkernbangan proses p e m b e n t u k a n P P T S P, penyelenggaraan pelayanan, capaian kinerja, kendala yang dihadapi, dan pembiayaan yang disampaikan secara berkala.

\section{HASIL DAN PEMBAHASAN \\ 1) Deskripsi Aktual Reformasi Birokrasi Pelayanan Perizinan}

Praktek reformasi birokrasi yang telah digulirkan di era reformasi telah membawa perubahan dalam pelaksanaan pemerintahan daerah. Salah satu perubahan itu adalah pemberian wewenang yang lebih luas dalam penyelenggaraan beberapa bidang pemerintahan daerah untuk mengatur struktur organisasi perangkat daerah dalam menyajikan pelayanan publik. Seiring dengan bertambah luasnya kewenangan ini, maka aparat birokrasi pemerintahan di daerah dapat mengelola dan menyelenggaraan pelayanan publik dengan lebih baik. Reformasi pelayanan perizinan yang dilakukan oleh pemerintah daerah secara umum juga masih parsial di mana reformasi dilandasi atas dasar kebutuhan dan desakan peraturan pusat. Orientasi penyelenggaraan pelayanan perizinan juga hanya terbatas pada aspek normatif semata. Mengintegrasikan kemudahan pelayanan perizinan masih sebatas wacana. Kuatnya pressure pada badan/kantor pelayanan perizinan usaha untuk Pendapatan Asli Daerah menjadi cermin bahwa orientasi jangka pendek reformasi perizinan masih dirasakan cukup kuat. Masuknya investasi ke daerah hanya dimaknai dengan semakin meningkatnya retribusi dan pajak daerah yang masuk ke kas daerah.

Fenomena lain yang juga mengemuka adalah kuatnya tarik- 
menarik kepentingan antar instansi teknis dalam mendelegasikan kewenangan beberapa pelayanan strategis kepada kantor/badan pelayanan terpadu. Kondisi ini kemudian diperparah oleh rendahnya komitmen kepala daerah dalam mendelegasikan kewenangan perizinan secara optimal pada otoritas kompeten yang dibentunya. Kompleksitas upaya format ulang birokrasi inilah yang disinyalir menjadi ruang bagi kepala daerah untuk tetap mengendalikan langsung beberapa kewenangan perizinan investasi yang strategis untuk mendukung langgengnya pengaruh kelompok politik golongan dalam struktur kekuasaan pemerintah daerah.Tindakan kontrol atas otoritas perizinan menjadi jalan untuk membangun komitmen dan loyalitas birokrasi dalam mencapai tujuan-tujuan politik kepala daerah, termasuk dalam upaya membangun oligarki kekuasaan. Pada saat yang sama, harapan perubahan pada gerakan masyarakat sipil dalam mengawal praktek reformasi birokrasi juga mennghadapi kendala. Menurut Fitri dkk (2011) kondisi civil society di Kabupaten Takalar juga masih sangat lemah dalam aspek transparansi dan akuntabilitas terhadap tata kelola pemerintahan daerah.

Berdasarkan urain tersebut, maka pelaksanaan pelayanan perizinan satu atap (One Stop
Service) yang dilaksanakan pemerintah daearah Kabupaten Gowa dan Kabupaten Takalar menghadapi karakteristik yang berbeda.

\section{a) Kabupaten Gowa}

1. Regulasi

Dalam menjalankan tugas pokok dan fungsi dalam pelayanan publik, pemerintah Kabupaten Gowa telah mendasarkan segala aktivitasnya pada visi Kabupaten Gowa yaitu : "Terwujudnya Gowa yang Handal dalam Peningkatan Kualitas Hidup Masyarakat". Terkait dengan pencapaian visi tersebut, maka Pemerintah kabupaten Gowa telah melakukan beberapa hal yang terkait dengan upaya reformasi birokrasi di bidang pelayanan perizinan.

Bentuknya adalah sejumlah produk regulasi yang terkait dengan upaya integrasi pelayanan perizinan.

Beberapa produk regulasi tersebut antara lain : 1. Perda No. 8 Tahun 2008 Tentang Organisasi \& Tata Kerja Lembaga Teknis Daerah Kabupaten Gowa.

2. Peraturan Bupati Gowa Nomor 36 Tahun 2009 Te $n$ t a $n g$ P e r u b a h a n Peraturan Bupati Gowa Nomor 49 tahun 2008 Tentang Tugas Pokok, Fungsi, Rincian Tugas Jabatan Struktural pada Kantor Pelayanan 
KEPENTINGAN POLITIK DAN EKONOMI KEPALA DAERAH DALAM REFORMASI BIROKRASI : KASUS REFORMASI PELAYANAN PERIZINAN DI KABUPATEN GOWA DAN KABUPATENTAKALAR

Andi Luhur Prianto

Te r p a d u K a b u p a t e n

Gowa.

3. Keputusan Bupati Gowa

Nomor 295/VIII/2010

Tanggal 9 Agustus 2010

Tentang Pendelegasian

Wewenang

Penandatanganan

Perizinan Kepada Kantor

P e 1 a y a $n$ a $n$ Te r p a d u

Kabupaten Gowa.

4. Keputusan Bupati Gowa

N o m o r 189 / I V / 2011

Tanggal 21 April 2011

Te $n \mathrm{t}$ a $\mathrm{ng} \mathrm{P}$ e $\mathrm{li} \mathrm{mp}$ a h a n

Kewenangan Pengelolaan

Perizinan Pada Kantor

$\mathrm{P}$ e 1 a y a $\mathrm{n}$ a $\mathrm{n}$ Te $\mathrm{r}$ p a d u

Kabupaten Gowa.

5. Surat Edaran Bupati

Gowa Nomor

03/I/HK/2011 Tanggal 10

$\mathrm{J}$ a n u a r i Te n t a n g

Penghapusan Pungutan

Retribusi TDI, TDP, IUP,

SITU, IKL, IUJK, Izin

Usaha Kepariwisataan, \&

Jasa Ketatausahaan

Berdasarkan data dan

kondisi dilapangan

ditemukan fakta bahwa

terjadi tarik-ulur kepentingan

dalam pelimpahan

$\mathrm{k}$ ew en an $\mathrm{g}$ an p elay an an perizinan.Beberapa jenis

layanan strategis cenderung dipertahankan oleh instansi teknis.Dalam praktek, pelimpahan kewenangan dilakukan dengan model "angsuran" sehingga penataan tugas pokok dan fungsi Kantor Pelayanan Terpadu (KPT) tidak bisa clear secara keseluruhan, dan menunggu tambahantambahan layanan yang sewaktu-waktu dilimpahkan.

Pada aspek substansi isi dari regulasi yang ada, umumnya masih terdapat pengaturan yang tidak sinkron antara peraturan yang dikeluarkan oleh pemerintah pusat sehingga pemerintah daerah sulit menerapkan peraturan tersebut secara konsisten. Pada satu pihak terkadang urusan pemerintah pusat seperti pertambangan, kehutanan, dan kelautan yang diserahkan kepada pemerintah daerah, tetapi peraturan sektoral masih menghendaki kuatnya tekanan sentralisasi pemerintah.

2. Kewenangan Kewenangan penyelenggaraan pelayanan terpadu didasarkan atas pendelegasian kewenangan, sebagaimana diatur dalam Perda No. 8 Tahun 2008 Tentang Organisasi \& Tata Kerja Lembaga Teknis Daerah Kabupaten Gowa dan berikut beberapa peraturan teknis tambahan. Kewenangan ini memberikan batasan-batasan jenis pelayanan terpadu yang disajikan, yang kemudian dijabarkan dalam bentuk Peraturan Bupati maupun Keputusan Bupati. Untuk jenis layanan yang menjadi 
KEPENTINGAN POLITIK DAN EKONOMI KEPALA DAERAH DALAM REFORMASI BIROKRASI : KASUS REFORMASI PELAYANAN PERIZINAN DI KABUPATEN GOWA DAN KABUPATEN TAKALAR

Andi Luhur Prianto

kewenangan Kantor Pelayanan Terpadu (KPT) kabupaten Gowa, terdiri dari 26 jenis yakni :

Tabel No. 1

Jenis Layanan Pada Kantor Pelayanan Terpadu (KPT) Kabupaten Gowa

\begin{tabular}{|l|l|}
\hline 1. Izin prinsip & 2. Izin Lokasi \\
\hline 3. Izin Gangguan (HO) & 4. Izin Kelayakan Lingkungan \\
\hline 5. Izin Tempat Usaha & 6. Izin Usaha Perdagangan \\
\hline 7. Tanda Daftar Perusahaan & 8. Tanda Daftar Industri \\
\hline 9. Tanda Daftar Gudang & 10. Izin Usaha Industri \\
\hline 11. Izin Usaha Jasa Konstruksi & 12. Izin Peruntukan Penggunaan Tanah \\
\hline 13. Izin Pemasangan Reklame & 14. Izin Mendirikan Bangunan \\
\hline 15. Izin Praktek Tenaga Kesehatan & 16. Izin Fasilitas Kefarmasian \\
\hline 17. Izin Makanan \& Minuman & 18. Izin Usaha Air Minum \\
\hline 19. Izin Usaha Produksi & 20. Izin Usaha Penyediaan Tenaga Listrik \\
\hline 21. Izin Usaha Kepariwisataan & 22. Izin Usaha Losmen/Penginapan \\
\hline 23. Izin Restoran/Rumah Makan & 24. Izin Hotel \\
\hline 25. Izin Usaha Travel & 26. Izin Usaha Hiburan \\
\hline
\end{tabular}

Sumber : Kantor Pelayanan Terpadu (KPT) Kab. Gowa, tahun 2011

Dari tabel No. 1

tersebut, maka tampak bahwa kewenangan kantor pelayanan terpadu hanya fokus pada bidang pelayanan perizinan, sementara jika merujuk pada ketentuan Permendagri Nomor 24

Ta h u n 2006 Te n t a n g Pelayanan Perizinan Terpadu Satu Pintu maupun UndangUndang Nomor 25 Tahun 2009 Tentang Pelayanan Publik menghendaki terjadinya integrasi pelayanan perizinan, melalui konsep pelayanan terpadu satu pintu. Bidang layanan yang tidak didelegasikan antara lain kewenangan tentang izin pertambangan (Gol. C) dan jasa-jasa lingkunganyang cukup strategis, masih berada di Sekretariat Daerah dan dibawah kontrol langsung kepala daerah.

3. Kelembagaan

Secara struktural Kantor Pelayanan Terpadu Kabupaten Gowa berada di bawah Bupati, yang organisasinya dipimpin oleh Kepala Kantor berada di bawah dan bertanggung jawab kepada Bupati. Dengan tugas pokok untuk melaksanakan penyusunan dan pelaksanaan kebijakan penyelenggaraan pemerintahan daerah yang bersifat spesifik di bidang pelayanan teradu yang 
KEPENTINGAN POLITIK DAN EKONOMI KEPALA DAERAH DALAM REFORMASI BIROKRASI : KASUS REFORMASI PELAYANAN PERIZINAN DI KABUPATEN GOWA DAN KABUPATEN TAKALAR

Andi Luhur Prianto

menjadi tanggung jawabnya berdasarkan kewenangannya sesuai dengan Permendagri Nomor 24 Tahun 2006 Tentang Pelayanan Perizinan Terpadu Satu Pintu maupun Undang-Undang Nomor 25 Ta h u n 2009 Te n t a n g Pelayanan Publik.

\section{b) Kabupaten Takalar}

1. Regulasi

Dalam fungsi dalam pelayanan publik, pemerintah Kabupaten Takalar telah mendasarkan segala aktivitasnya pada visi yaitu :"Menjadi Pemerintah Kabupaten Takalar yang Amanah". Terkait dengan pencapaian visi tersebut, maka Pemerintah kabupaten Takalar telah melakukan beberapa hal yang terkait dengan upaya reformasi birokrasi di bidang pelayanan perizinan. Bentuknya yang nyata adalah dengan disahkannya kelembagaan yang terkait dengan upaya integrasi pelayanan perizinan, yakni Peraturan Daerah Nomor 12 Tahun 2008 Tentang Organisasi dan Tata Kerja Lembaga Teknis daerah Kabupaten Takalar.

Rumpun regulasi dalam bentuk Peraturan Daerah sebenarnya belum bersifat teknis sehingga masih perlu penjabaran-penjabaran yang lebih detail terkait dengan tugas pokok dan fungsi lembaga. Kurang lengakapnya regulasi yang terkait perizinan, masih didasarkan oleh beberapa peraturan terdahulu kelembagaan tersebut masih berbentuk UPTD SIMTAP. Berdasarkan data dan kondisi dilapangan ditemukan fakta bahwa tidak adanya regulasi untuk beberapa jenis layanan perizinan membuat reformasi birokrasi pelayanan menjadi kurang bermakna. Beberapa jenis layanan strategis seperti izin usahaindustri,

pertambangan, perhotelan, serta jasa usaha wisata cenderung dipertahankan oleh instansi teknis dan berada dibawah kekuasaan sang kepala daerah.

\section{Kewenangan}

Kewenangan penyelenggaraan pelayanan terpadu didasarkan atas pendelegasian kewenangan, sebagaimana diatur dalam yakni Peraturan Daerah Nomor 12 Tahun 2008 Tentang Organisasi dan Tata Kerja Lembaga Teknis daerah Kabupaten Takalar. Kewenangan lembaga yang di sedikit berubah, dari UPTD menjadi Kantor ini tidak diikuti oleh petubahan jumlah kewenangan jenis layanan. Kewenangan jenis layanan Kantor Pelayanan Te r p a d u ( K P T) mas i h cenderung mempertahankan kewenangan yang dimiliki 
KEPENTINGAN POLITIK DAN EKONOMI KEPALA DAERAH DALAM REFORMASI BIROKRASI : KASUS REFORMASI PELAYANAN PERIZINAN DI KABUPATEN GOWA DAN KABUPATEN TAKALAR

Andi Luhur Prianto

UPTD SIMTAP (Sistem

Informasi Manajemen Satu
Atap) sejak Tahun 2002

sebelumnya :

Tabel No. 2

Jenis Layanan Pada Kantor Pelayanan Terpadu (KPT)

Kabupaten Takalar

\begin{tabular}{|l|l|}
\hline \multicolumn{1}{|c|}{ Layanan Non Perizinan } & \multicolumn{1}{c|}{ Layanan Perizinan } \\
\hline Kartu Tanda Penduduk (KTP) & Izin Gangguan (Hinder Ordonatie / HO) \\
\hline Kartu Keluarga (KK) & Izin Mendirikan Bangunan (IMB) \\
\hline Akte Kelahiran & Surat Izin Usaha Perdagangan (SIUP) \\
\hline Akte Kematian & Tanda Daftar Gudang (TDG) \\
\hline Kartu Kuning & Tanda Daftar Perusahaan (TDP) \\
\hline & Tanda Daftar Industri Kecil (TDIK) \\
\hline & Tanda Daftar Industri (TDI) \\
\hline & Izin Usaha Jasa Konstruksi (IUJK) \\
\hline & Mutasi PBB \\
\hline & Izin Lokasi \\
\hline & Izin Reklame \\
\hline
\end{tabular}

Sumber : Kantor Pelayanan Terpadu (KPT) Kab. Takalar, tahun 2011

Dari tabel No. 2

tersebut, maka tampak bahwa kewenangan kantor pelayanan terpadu tidak hanya fokus pada bidang pelayanan perizinan, tetapi juga layanan non perizinan. Hal lain yang tidak didelegasikan antara lain kewenangan tentang izin pertambangan (Gol. C) dan jasa-jasa lingkungan yang cukup strategis, masih berada dibawah kontrol langsung kepala daerah.

3. Kelembagaan

Secara struktural

Kantor Pelayanan Terpadu Kabupaten Takalar berada di bawah Bupati, yang organisasinya dipimpin oleh Kepala Kantor berada di bawah dan bertanggung jawab kepada Bupati.Tugas pokok instansi ini adalah melaksanakan urusan di bidang pelayanan perizinan secara terpadu berdasarkan asas desentralisasi dan tugas pembantuan

\section{2) Kaitan-Kaitan Kepentingan Politik Kepala Daerah Dalam Reformasi Birokrasi}

Birokrasi pemerintah daerah hingga saat ini masih belum efektif memainkan peran dalam memenuhi tuntutan publik. Mereka tidak dapat merubah diri sendiri dan hanya dapat termangu menyaksikan situasi ekonomi, sosial dan politik yang sikap dinamis dan terbuka. Efektifitas waktu dan efisiensi biaya yang tidak terukur adalah bukti rendahnya kualitas kinerja birokrasi. Inilah cermin budaya 
KEPENTINGAN POLITIK DAN EKONOMI KEPALA DAERAH DALAM REFORMASI BIROKRASI : KASUS REFORMASI PELAYANAN PERIZINAN DI KABUPATEN GOWA DAN KABUPATEN TAKALAR

Andi Luhur Prianto

birokrasi kita saat ini yang jauh dari kesan sebagai pelayan. Perubahan kepemimpinan yang terjadi di tingkat nasional maupun daerah ternyata tidak mampu mendorong reformasi yang terarah dalam upaya memperbaiki citra aparatur dan sistem birokrasi pemerintah daerah.

a) Kepentingan Politik

Dalam praktek reformasi pelayanan perizinan di daerah, arah perubahan pada aras struktur dan proses yang dibangun lebih merupakan instrumen untuk membangun loyalitas birokrasi dalam mewujudkan tujuan-tujuan politik kepala daerah, seperti membangun oligarki keluasaan, bukan untuk membangun komitmen pada optimalisasi pelayanan kepada masyarakat. Bangunan struktur birokrasi dikendalikan oleh kepala daerah dan diorientasikan untuk memenuhi tujuan politik melalui mekanisme dan prosedur pelayanan publik yang untuk memenuhi target pendapatan bagi jejaring politik kepala daerah. Prosedur dan norma pelayanan perizinan tidak berjalan sebagaimana ketentuan normatif, tetapi sangat dipengaruhi oleh momentummomentum politik. Birokrasi pelayanan perizinan diarahkan untuk merangkul dukungan kalangan investor untuk kepentingan kepala daerah. Penguatan struktur kelembagaan pelayanan perizinan melalui program reformasi birokrasi perizinan lebih berfungsi untuk mengendalikan perilaku dan menjaga ikatan loyalitas antara kepala daerah dengan investor sehingga seolah-olah kemudahan pelayanan berasal dari "kumurahan hati" sang kepala daerah. Pada kasus digratiskannya beberapa jenis layanan retribusi pada Kantor Pelayanan Terpadu (KPT) Kab. Gowa lebih bermakna sebagai upaya sang kepala daerah untuk mempertahankan legitimasi kepemimpinan sang kepala daerah, meskipun beberapa jejaring birokrasi teknis masih sulit melaksanakannya. Sementara pada kasus digratiskannya beberapa jenis layanan non perizinan (terutama layanan adminsitrasi kependudukan) pada pada Kantor Pelayanan Terpadu (KPT) Kab.Takalar biasanya dikaitkan dengan momentum pemilihan kepala daerah. Fenomena ini menujukkan bahwa betapa kuatnya tekanan politik yang mesti dihadapi oleh birokrasi pelayanan terpadu satu atap (PTSP), dalam mengoptimalkan kinerja pelayanan pada masyarakat. Misi utama birokrasi pemerintah daerah tidaklah berbeda dengan perilaku birokrasi kolonial, yakni untuk mempertahankan kekuasaan dan mengontrol perilaku individu. Indikasi lain yang mendukung sinyalemen tersebut juga dapat dilihat dari pengisian formasi jabatan pada stuktur pelayanan yang strategis umumnya diisi para birokarat yang memiliki 
ikatan loyalitas dangan sang kepala daerah. Dengan demikian terjadi simbiosis mutualisme antar birokrat dan politisi untuk menjadikan birokrasi sebagai lahan pemenuhan hasrat dan kekuasaan (power culture).Dengan kata lain, birokrasi pemrintah daerah adalah alat kendali bagi kepala daerah yang paling mudah digunakan untuk mengontrol perilaku masyarakat, sekaligus dapat dimanfaatkan untuk mempertahankan klan dan oligarki kekuasaan. Pada titik inilah idea-idea reformasi birokrasi yang sampai di daerah belum berjalan optimal.

b) Kepentingan Ekonomi Kualitas pelayanan publik di bidang perizinan memainkan peran strategis dalam menarik investor untuk menanamkan modalnya di suatu daerah, yang secara agregat memberi pengaruh pada pertumbuhan ekonomi daerah. Kualitas pelayanan perizinan sendiri juga dapat diidentifikasi dari peraturan pemerintah daerah dalam mendukung sekaligus memberikan legitimasi lembaga perizinan di daerah untuk memberikan pelayanan secara lebih efisien dan efektif. Dalam praktek reformasi birokrasi pelayanan perizinan masih menghadapi banyak kendala kepastian, terutama dari waktu, biaya dan prosedur.Hasil temuan pada Kantor Pelayanan Terpadu (KPT) di Kabupaten Gowa dan Kabupaten Takalar menujukkan bahwa terdapat sikap inkonsistensi dan komitmen yang rendah dari kepala daerah untuk menyerahkan keseluruhan wewenang pelayanan perizinan kepada otoritas pelayanan terpadu yang bentuknya. Motif ekonomi melalui modus $\mathrm{p}$ e $\mathrm{mb}$ e b a n a $\mathrm{t}$ a rg e $\mathrm{t}-\mathrm{t}$ a rg e $\mathrm{t}$ pendapatan anggaran daerah pada masing-masing perangkat birokrasi daerah menjadi bagian dari kompleksitas upaya integrasi wewenang pelayanan yang terkait dengan perizinan investasi. Untuk Kabupaten Takalar beberapa jenis layanan investasi strategis dilakukan oleh Kantor Penanaman Modal dan Lingkungan Hidup, yang memerlukan izin prinsip langsung dari sang kepala daerah. Sementara modus serupa juga terjadi di Kabupaten Gowa, dimana izin-izin investasi usaha pertambangan masih menjadi domain Sekretariat Daerah c.q. Bagian Ekonomi Pembangunan, yang dikendalikan langsung oleh sang kepala daerah.

Kuatnya kewenangan kepala daerah untuk tetap mengendalikan beberapa jenis layanan strategis sebab dianggap sangat menjanjikan suatu pola "transaksi" politik dan ekonomi antara kepala daerah dan dengan pi hak in ve s tor. P ol a transaksional yang terjadi berupa lahirnya komitmen dan dukungan politik dari pihak investor sekaligus keuntungan ekonomi bagi kelompok politik kepala daerah sementara kepala 
KEPENTINGAN POLITIK DAN EKONOMI KEPALA DAERAH DALAM REFORMASI BIROKRASI : KASUS REFORMASI PELAYANAN PERIZINAN DI KABUPATEN GOWA DAN KABUPATEN TAKALAR

Andi Luhur Prianto

daerah akan menyediakan insentif dan fasilitas penunjang investasi bagi pihak investor. Hal dapat di temukan dengan kemudahan perizinan usaha industri air mineral dan pertambangan meskipun aktivitas usaha tersebut tidak sesuai dengan ketentuan Rencana Tata Ruang Wilayah (RTRW) Kabupaten yang ada. Fenomena lainyang ditemukan dari studi lapang yang dilakukan adalah kuatnya kepentingan ekonomi di balik reformasi birokrasi perizinan dengan modus memberi target yang tinggi pada instansi pelayanan perizinan untuk mencapai realisasi Pendapatan Asli Daerah (PAD) setiap tahunnya. Trend peningkatan Pendapatan Asli Daerah (PAD) juga menjadi indikator keberhasilan kepemimpinan kepala daerah.

Tabel No.3

Perkembangan Pendapatan Asli Daerah (PAD) Kabupaten Gowa \& Kabupaten Takalar

\begin{tabular}{|c|l|r|r|c|c|}
\hline \multirow{2}{*}{ No } & \multirow{2}{*}{ Kabupaten } & \multicolumn{4}{|c|}{ Realisasi Pendapatan Asli Daerah (PAD) } \\
\cline { 3 - 6 } & & Tahun 2006 & Tahun 2007 & Tahun 2008 & Tahun 2009 \\
\hline 1 & Gowa & 35.703 .518 .160 & 33.371 .641 .773 & 45.827 .484 .393 & 49.522 .385 .717 \\
\hline 2 & Takalar & 8.974 .000 .000 & 9.395 .475 .000 & 13.213 .550 .000 & 13.776 .416 .000 \\
\hline
\end{tabular}

Sumber : RPJMD Kab. Gowa 2010-2015 Dan Takalar Dalam Angka Tahun 2009 \& 2011

Upaya untuk terus meningkatkan pendapatan sebagai salah satu output keberhasilan reformasi birokrasi perlu di cermati dengan hatihati. Perilaku kehati-hatian penting sebab beban dan target pelayanan terkadang tidak proporsional dengan besaran kewenangan, kelembagaan, sumberdaya, support anggaran, serta sarana dan prasarana yang dimiliki instansi pelayanan perizinan.

Pada konteks ini, reformasi birokrasi pada akhirnya menjadi program yang dilakukan "setengah hati" dan miskin terobosan. Oleh karena itu, perlu dilakukan inovasi baru dalam penciptaan budaya ( cultural innovation and invention) dalam birokrasi, sehingga budaya birokrasi yang responsif terhadap kebutuhan rakyat dan tidak menjadi alat untuk melanggengkan kekuasaan.

\section{PENUTUP \\ 1) Kesimpulan}

Reformasi pelayanan perizinan yang dilakukan oleh pemerintah daerah, yakni kabupaten Gowa dan Kabupaten Takalar masih bersifat ambivalen. Artinya bahwa perubahan yang ada terjadi mengikuti prosedur normatif tetapi perubahan itu kemudian arahkan untuk kepentingan politik dan ekonomi kepala daerah. Pada kedua daerah ini, karakter strong leadership yang dimiliki kepala daerah memungkinkan terjadinya 
upaya pemenuhan tujuan politik, dengan mekanisme kontrol perilaku aparatur untuk membangun loyalitas politik pada birokrasi serta tujuan ekonomi, melalui mekanisme dan prosedur pelayanan publik yang untuk memenuhi target pendapatan daerah.Fenomena ini menjadi cermin bahwa arah dan orientasi dari praktek reformasi pelayanan perizinan di daerah masih jauh dari harapan publik. Ikhtiar untuk mengintegrasikan kemudahan pelayanan perizinan masih terkendala pada rendahnya komitmen dan kepentingan politik dan ekonomi dari sang kepala daerah yang terus berupaya melanggengkan oligarki kekuasannya.

\section{2) Saran}

Reformasi birokrasi yang terjadi selama ini cenderung bermakna sebagai perombakan struktur, mesti bergeser pada perubahan nilai dan budaya birokrasi. Tentu hal ini bukanlah pekerjaan mudah ditengah tarikan ekonomi dan politik dari kepala daerah. Meski sulit, tetapi ikhtiar itu harus terus diarus-utamakan dengan melengkapi penataan dari aspek regulasi, kewenangan, dan kelembagaan sehingga tercipta birokrasi pemerintah daerah yang totally mengabdi pada kepentingan rakyat.

\section{DAFTAR PUSTAKA}

Atmoko dkk, Tjipto. 2007, Pengukuran Kualitas Pelayanan Administrasi Penanaman Modal Di Kabupaten Garut, .
Laporan Penelitian : Pusat Penelitian Kebijakan Publik dan Pengembangan Wilayah Universitas Padjadjaran Bandung.

Dwiyanto, Agus et al. 2006. Reformasi Birokrasi Publik di Indonesia. Yogyakarta : Gadjah Mada University Press

Hardjapamekas, Erry Riana. 2003. Reformasi Birokrasi: Tantangan dan Peluang, Jakarta : Badan Pembinaan Hukum Nasional

Insani, Istyadi, 2010. Penyusunan Standar Operasional Prosedur Dalam Reformasi Birokrasi Sebagai Business Process Reengineering Birokrasi Pemerintah, Makalah ini disajikan dalam Konferensi Administrasi Negara III di Bandung pada tanggal 6-8 Juli 2010.

Jasin dkk, Muhammad. 2007. Implementasi Layanan Terpadu Di Kabupaten/Kota Studi Kasus :Kota Yogyakarta, Kabupaten Sragen, Kota Parepare, Jakarta : Litbang KPK

KPK, 2011. Penilaian Inisiatif Anti Korupsi (PIAK) 2011, Jakarta : Litbang KPK

Mullatto, dkk. 2007. Pengembangan Pelayanan Terpadu Satu Pintu Oleh Perangkat Daerah Kab/Kota Di Jawa Tengah, Semarang : Balibangda Jawa Tengah

Mursitama dkk, Tirta Nugraha. 2010.

Reformasi Pelayanan Perizinan Dan Pembangunan Daerah: Cerita Sukses Tiga Kota (Purbalingga, Makassar, 
KEPENTINGAN POLITIK DAN EKONOMI KEPALA DAERAH DALAM REFORMASI BIROKRASI : KASUS REFORMASI PELAYANAN PERIZINAN DI KABUPATEN GOWA DAN KABUPATEN TAKALAR

Andi Luhur Prianto

Dan Banjarbaru), Jakarta : MTI

Nugroho, Riant. 2010.ImplantBusiness

Process Reengineering for

Bureaucracy: Ideas and

Obsession, Materi Workshop

Business Process

Reengineering Birokrasi

Pemerintah yang

diselenggarakan Kementrian

PAN \& RB pada tanggal 29

April 2010 di Kantor

Kementerian PAN \& RB

Jakarta;

Priyanta, Maret dkk. 2008. Pelayanan

Perizinan Terpadu Satu Pintu

Bagi IndustriDalam Upaya

Pelestarian Fungsi

LingkunganDi Kota Cimahi,

Laporan Akhir

PenelitianFakultas Hukum

Universitas Padjadjaran.

TII. 2011, Indeks Persepsi Korupsi

(Corruption Perception

Index/CPI) tahun

2011http://ti.or.id/index.php /news/2011/12/02/indonesia -peringkat-ke-100-indeks-

pers e p s i - k o r u p s i - 2011

(diakses tanggal $01 \mathrm{Mei}$

2012)

Dokumen Publik

UU No. 28 Tahun 1999 tentang

Penyelenggaraan Negara

Yang Bersih dan Bebas dari

Korupsi, Kolusi, dan

Nepotisme,

UU No. 32 Tahun 2004 Tentang

Pemerintahan Daerah,

UU No. 25 Tahun 2009 Tentang

Pelayanan Publik

Peraturan Presiden No. 81 Tahun 2010

Tentang Grand Desaign

Reformasi Birokrasi 2010-

2025 ,
Peraturan Menteri Dalam Negeri No. 24 Tahun 2006 tentang Pelayanan Perizinan Terpadu Satu Pintu

Perda No. 12 Tahun 2008 Tentang Organisasi dan Tata Kerja Lembaga Teknis Daerah Kabupaten Takalar

Perda No.8 Tahun 2008 Tentang Organisasi \& Tata Kerja Lembaga Teknis Daerah Kabupaten Gowa

Peraturan Bupati Gowa Nomor 36 Ta h u n 2009 Te n t a n g Perubahan Peraturan Bupati Gowa Nomor 49 tahun 2008 Tentang Tugas Pokok, Fungsi, Rincian Tugas Jabatan Struktural pada Kantor Pelayanan Terpadu Kabupaten Gowa

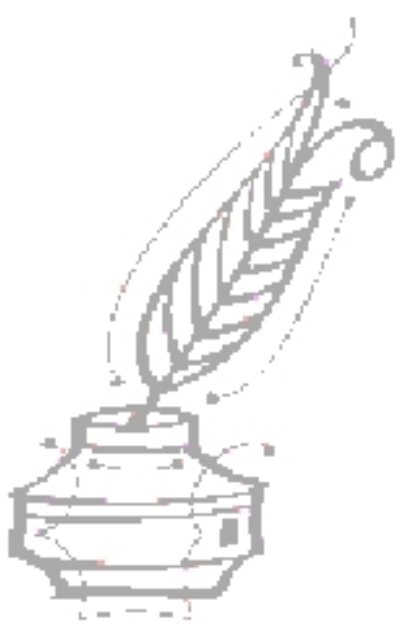

